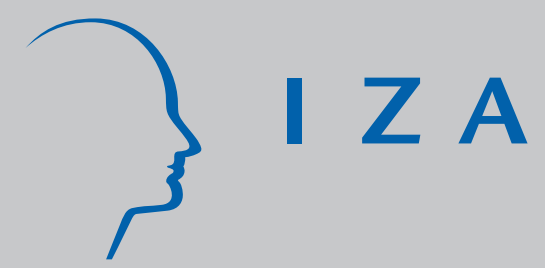

IZA DP No. 9025

The Local Economic Impact of Wind Power Deployment

Nils G. May

Øivind A. Nilsen

April 2015

Forschungsinstitut zur Zukunft der Arbeit Institute for the Study of Labor 


\title{
The Local Economic Impact of Wind Power Deployment
}

\author{
Nils G. May \\ DIW Berlin \\ Øivind A. Nilsen \\ Norwegian School of Economics \\ and IZA
}

Discussion Paper No. 9025

April 2015

IZA

P.O. Box 7240

53072 Bonn

Germany

Phone: +49-228-3894-0

Fax: +49-228-3894-180

E-mail: iza@iza.org

Any opinions expressed here are those of the author(s) and not those of IZA. Research published in this series may include views on policy, but the institute itself takes no institutional policy positions. The IZA research network is committed to the IZA Guiding Principles of Research Integrity.

The Institute for the Study of Labor (IZA) in Bonn is a local and virtual international research center and a place of communication between science, politics and business. IZA is an independent nonprofit organization supported by Deutsche Post Foundation. The center is associated with the University of Bonn and offers a stimulating research environment through its international network, workshops and conferences, data service, project support, research visits and doctoral program. IZA engages in (i) original and internationally competitive research in all fields of labor economics, (ii) development of policy concepts, and (iii) dissemination of research results and concepts to the interested public.

IZA Discussion Papers often represent preliminary work and are circulated to encourage discussion. Citation of such a paper should account for its provisional character. A revised version may be available directly from the author. 


\section{ABSTRACT}

\section{The Local Economic Impact of Wind Power Deployment ${ }^{\star}$}

Globally installed wind power capacity has grown tremendously since 2000 . This study focuses on the local economic impacts of wind power deployment. A theoretical model shows that wind power deployment is not necessarily driven by locally-accruing economic payoffs, but also by other factors such as emphasis on environmentally-friendly energy production and its associated benefits. The theoretical analysis is followed by an empirical analysis using German county-level panel data. After controlling for a set of observable and unobservable factors, the results state that wind power installation has no impact on GDP per capita. These findings support the predictions from the theoretical model: local economic impacts cannot alone explain the observed increase in wind power capacity.

JEL Classification: Q42, R11, C23

Keywords: wind power, economic development, panel data

Corresponding author:

Øivind A. Nilsen

Department of Economics

Norwegian School of Economics

Hellevn. 30

$\mathrm{N}-5045$ Bergen

Norway

E-mail: oivind.nilsen@nhh.no

\footnotetext{
* This paper benefitted from fruitful discussions with Gunnar Eskeland, Dan Gordon, Claudia Kemfert, Johannes Mauritzen, Grant McDermott, Patrick Narbel, Linda Nøstbakken, Nico Pestel, and Anders Skonhoft, as well as comments and suggestions during presentations at the Norwegian School of Economics, the DIW Berlin and the Ifo-institute, Munich. The free provision of data by the German Weather Service (DWD) and the Ingenieurswerkstatt Energietechnik (IWET) is greatly appreciated. The paper was partly written while Nilsen was visiting the Center for Macroeconomic Research University of Cologne (CMR), whose hospitality is gratefully acknowledged. The usual disclaimer applies.
} 


\section{Introduction}

Global wind power deployment has surged since 2000. At that point only 18 gigawatts (GW) of capacity were installed worldwide. By the end of 2014, this has soared to about $370 \mathrm{GW}$ (Global Wind Energy Council, 2015). China, the United States and Germany are at the forefront of this development, with Germany leading in the early 2000s, while China and the US have subsequently taken the lead. Many other countries, e.g. India, Canada, and Spain, have, to various degrees, also increased their annually installed capacity since 2005 . This worldwide growth of wind capacity fosters energy independence (Yue et al., 2001) and usually costs less than other renewable energies like solar power (International Energy Agency, 2012). Further, wind energy production has the advantage of usually being spatially decentralized and, thus, it has the potential to encourage economic development to a variety of local regions. Consequently, many industrialized and emerging countries are actively supporting renewable energies through legislative and policy initiatives (among them China, the US, the EU countries and many developing countries, see, for instance, Ren21, 2014).

However, the actual economic consequences for the counties where wind power capacity is installed are not clear. National- and state-wide economic outcomes have received considerably more attention. At the local level, the potential positive factors include increased incomes/revenues for those employees and companies employed either during the construction period or once the facility is operational. Lease payments to landowners, for externally-owned installations, and earnings/losses for locally-owned installations, are positive factors. On the other hand, wind power development has the potential to negatively impact other aspects, including tourism, the desire of people to live in a certain region, demand for land, as well as the availability of employees for other projects. Furthermore, as a consequence of a growing wind industry, regular thermal power plants could receive less investment and employ fewer, 
thus being crowded out. Whether or not wind farms are implemented depends largely on the inherent perception that both local authorities and the population have of the local economic impacts (Mulvaney et al., 2013; Toke, 2005). ${ }^{1}$ In addition, several factors might affect the economic consequences of the establishment of wind power plants, such as a region's economic prosperity and its degree of urbanization and industrialization. For instance, one could argue that the greater its capability of participating in the construction site and maintenance work, the more a region benefits from wind power installations.

Not surprisingly do the estimates of the local economic effects of wind power instalments vary a lot. Brown et al. (2012) conduct an empirical analysis of local economic effects in wind-rich regions in the US. In their quasi-cross-sectional approach, they find that per capita labor income at the county-level is increased by 11,500 USD/MW. Other studies scrutinize the local economic effects using ex-ante model analyses like Input-Output and computable general equilibrium (CGE) models. For instance, Slatterya et al. (2011) conclude that the gains for the respective counties lie at 2,600 USD/MW in Texas. Focusing on a region in Oklahoma, Greene and Geisken (2013) find an increase in local gains by 9,730 USD/MW. Bristow et al. (2012) conclude that in Wales, the economic incentives from the installations are rather marginal, so that Welsh counties have little interest in proceeding with wind power projects. Furthermore, potential investors often pay "community benefits" in order to gain local acceptance. Similarly, Munday et al. (2011) find only small economic benefits for the involved counties in Wales. Furthermore, they state that such community benefits also exist in other parts of the UK. In their analysis, Allan et al. (2011) furthermore find that forms of community benefits outweigh the importance of local sourcing. Schröder (2010) dissects the economic impacts of hypothetical wind turbine deployment in Hannover, Germany. He concludes that

\footnotetext{
${ }^{1}$ Hitaj (2013) finds that federal production tax credit, state-level sales tax credit and production incentives, together with access to the electricity transmission grid play important roles in promoting wind power development in the United States.
} 
"the construction and the operation of wind power systems in the region Hannover do not have any significant meaning for the region's economy" (p.75).

In this study the effect of wind power capacity on the economic development at the local level is operationalized by using information at the county level ("Landkreise" and "Kreisfreie Städte") in Germany. Gross Domestic Product (GDP) per capita is used as the dependent variable, an often-utilized indicator of general economic welfare (Barro, 1991). The channels through which communities can benefit or lose from wind projects are likely to be captured through this measure. If investments, spending or revenues are affected in any areas of the local economy, this will be reflected in an increase or decrease of GDP per capita. Using German data for the purpose of the analysis has several advantages. Germany has been a forerunner when it comes to governmental support of renewable energies through the use of feed-in tariffs (Butler and Neuhoff, 2008). In addition to national support schemes, local legislation plays an important role for the installation of wind turbines. In Germany, regional decision bodies designate appropriate areas through zoning (land development plans: "Flächennutzungspläne”) and conduct the approval processes (Schröder, 2010). Over the 2002-09 sample period, IWES (2012) numbers show that the installed wind capacity increased from 11,860 to more than 25,000 Megawatts. In 2013, it represented about $7.9 \%$ of the gross electricity production, making it the leading renewable electricity source, ahead of biomass (6.8\%), photovoltaic (4.5\%), hydro power (3.4\%) and residual waste (0.8\%) (Statista, 2014). Furthermore, according to the "Energy concept" and the German Energiewende, at least $80 \%$ of gross electricity consumption should be met by renewable sources by 2050 (BMU, 2011). Thus, wind energy deployment is of major importance for the German electricity market and its economy.

This study contributes to the literature by assessing the local economic impacts of wind power deployment using panel-type of data. Except Brown et al. (2012), who use a quasi-crosssectional approach, most existing studies analyze single wind power deployment projects 
instead of conducting analyzes on average outcomes. Through the use of panel data, the potential endogeneity and selection issues - if the installation of wind power is affected by effects of unobserved, individual factors in the counties - can be addressed. ${ }^{2}$ This approach allows for feedback processes between GDP per capita growth and the installation of wind power. To the authors' best knowledge, this is also the first empirical analysis of the local economic effects of wind power deployment for Germany.

The initial pooled OLS results show that installed wind power capacity has a statistically significant positive impact on GDP per capita. This positive effect disappears once unobserved background characteristics are controlled for by using panel data estimation methods. These panel methods can be seen as ways to control for unobserved selection effects on unobservables. Such selection could occur if turbines are installed in counties depending on the quality of the infrastructure, the political environment, the efficiency and structure of its administration, and cultural differences. Several robustness checks, including panel IV estimation techniques, a dynamic specification, and testing for cross-sectional dependency (neighbourhood effects), support the lack of a statistical significant effect of wind power installations.

The remainder of the paper is structured as follows. Section 2 includes a short conceptual framework for the empirical analysis. Section 3 describes the data used and the econometric approach. Section 4 presents the results from the estimation. Finally, in Section 5 some concluding remarks are made.

\footnotetext{
${ }^{2}$ It could be argued, as for instance Brown et al. (2012) do, that empirical assessment have the advantage over model-based simulations that they yield ex-post actual outcome-based insights, rather than ex-ante model simulations. These latter approaches include for instance econometric input-output (see for instance Rey 2000) and the CGE approach (see for instance Turner et al. 2012). Note however that these last estimation approaches scrutinize only particular, individual outcomes, whereas empirical ex-post analyses can do so for average, nation-wide outcomes.
} 


\section{Conceptual Framework}

A simplifying, yet not too unrealistic, assumption is that the counties are the actual land owners, as these local authorities do indeed shape the industry composition and land usage to a large extent through zoning decisions and policies. The utility function of a county is

$$
\mathrm{u}(y, R, e \cdot W)
$$

where $y$ denotes the income, which is equal to the expenditures, $R$ the zones used for recreation (or non-income generating activities), and $W$ the zones assigned to wind parks. It is furthermore assumed that the county prefers more of each of $y, R$, and $W$, i.e. $\mathrm{u}_{\mathrm{y}}>0$, $\mathrm{u}_{\mathrm{R}}>0$, and $\mathrm{u}_{\mathrm{w}}>0 .^{3}$ The separate inclusion of $W$ in the utility function is meant to capture that factors associated with wind power other than just local economic outcomes might also affect the zoning decisions. Such factors can exist for a multitude of reasons; a reduction in greenhouse gas emissions and therefore less carbon-intensive electricity production, less dependency on fossil fuel imports, an active industry policy opting for wind power that can lead to a comparative advantage for German industries, and potentially enabling increased exports and therefore long-term employment effects. ${ }^{4}$ The $e$ is a shift parameter such that a larger $e$ induces more weight of $W$ in the utility function.

The county faces the following two constraints

$$
\begin{aligned}
& y=r \cdot W+v \cdot O+V \\
& T=R+W+O
\end{aligned}
$$

where $r$ is rent for wind usage, $W$ denotes the area used for wind power production, $v$ is the rent from income-generating activities (other than wind usage), $O$ areas used for other income

\footnotetext{
${ }^{3}$ In addition, diminishing marginal utilities are assumed, i.e. .e. $\mathrm{u}_{\mathrm{yy}}<0, \mathrm{u}_{\mathrm{RR}}<0$, and $\mathrm{u}_{\mathrm{ww}}<0$.

${ }^{4}$ These latter effects are admittedly most relevant at a national level, and only to a smaller degree at the local level. But due to the political processes, they are also likely to play a role at the local level.
} 
generating activities, $V$ transfers to the county unrelated to the use of the area, and $T$ the total amount of land available. Now the budget constraint can be re-written as

$$
y=(r-v) \cdot W+v \cdot(T-R)+V
$$

This static model can be formulated as a Lagrange function ${ }^{5}$

$$
\mathrm{L}=\mathrm{u}(y, R, e \cdot W)-\lambda \cdot(y-(r-v) \cdot W-v \cdot(T-R)-V)
$$

The first order conditions (FOC) are

$$
\begin{aligned}
& \mathrm{dL} / \mathrm{dy}=\mathrm{u}_{\mathrm{y}}-\lambda=0 \\
& \mathrm{dL} / \mathrm{dR}=\mathrm{uR}_{\mathrm{R}}-\lambda \cdot v=0 \\
& \mathrm{dL} / \mathrm{dW}=e \cdot \mathrm{u}_{\mathrm{w}}+\lambda \cdot(r-v)=0
\end{aligned}
$$

Holding equations $(5 a)$ and $(5 c)$ together results in the following expression ${ }^{6}$

$$
\mathrm{e} \cdot \mathrm{u}_{\mathrm{w}} / \mathrm{u}_{\mathrm{y}}=v-r
$$

Eq. (6) shows that the loss of utility because a county wants wind power instead of income, i.e. the cost of valuing other factors than just local economic outcomes associated with wind parks, should equal the difference in income from $O$ and $W$. This states that the disutility of forgone income from $O$ should equal the utility from the other factors associated with wind power. Furthermore, this eq. equation shows that if the shift parameter $e$ increases, i.e. that wind power becomes more important in the utility function, this has the same effect as an increase in the difference in the rental prices of the two income-generating alternatives of land usage. Given that $\mathrm{u}_{\mathrm{w}}>0$ and $\mathrm{u}_{\mathrm{ww}}<0$, one would then see increased $W$. Therefore, factors other than just local

\footnotetext{
${ }^{5}$ It is also worth pointing out that if politicians do not value any other factors of wind power, i.e. if zoning decisions were driven only by local pecuniary considerations, this could be modelled as $\mathrm{u}(y$, $W+O$ ). Then one would only observe $R+W$, or $R+O$, and not $R+W+O$. This is not what is likely to be found; several municipalities have both $W$ and $O$ (in addition to $R$ ). Thus, this indicates that the utility function should be written as $\mathrm{u}(y, R, e \cdot W)$.

${ }^{6}$ The equations (5a) and (5b) can be rewritten as $v=\mathrm{u}_{\mathrm{R}} / \mathrm{u}_{\mathrm{y}}$

which states that in equilibrium, the marginal rate of substitution between $R$ and $y$ equals the opportunity costs of using the land only for recreation. Said differently, the disutility of giving up one unit of recreation area $R$ is equal to the utility-gain of higher expenditures times the opportunity costs per unit $v$.
} 
economic considerations affect zoning decisions; even in case of constant pecuniary transfers $r$ for a wind project. Furthermore, increased demand for wind park areas, perhaps triggered by increased subsidies/transfers to wind park owners, would drive up the rental price of land, $r$. For the equality in eq. (6) to hold, this would mean a decrease in $u_{w}$. This, along with $u_{w w}<0$ again, would yield an increase in $W$.

Thus, the framework shows that both pure local financial considerations and other factors can be drivers of wind power development at the regional level. Naturally, the relative weight on financial and other factors is likely to be very different across regions (countries, counties) due to unique political landscapes and constituencies. Previous research on US counties, for example, finds that the economic factors could very well play an important role in the development of wind power projects, as they do materialize (Brown et al., 2012). In case of the UK, however, this does not appear to be the whole story. Community benefits are often additionally paid to the involved communities in the form of increased pecuniary transfers, $r$ (Munday et al., 2011). For Germany, the substantial increase in land allocated to wind power could be driven by such local financial incentives or, possibly, other factors linked to wind power.

\section{Data Description and Econometric Strategy}

\subsection{Data}

The panel data set is based on annual data for the 2002 to 2009 period for German counties. 2002 was selected as the starting point for several reasons: First, the German feed-in-tariff underwent a major reform in 2001 (e.g. Butler and Neuhoff, 2008), such that the potential impacts of wind power installations may have been significantly affected, as they are possibly dependent on the order of magnitude and regulations of the feed-in tariff. Furthermore, due to the large technological changes since then, wind turbines from before 2002 are officially 
considered to be technologically outdated and are available for special repowering feed-in tariffs (German Bundestag, 2011). The analysis goes until 2009 as it is the most recent year for which (almost) all data was available. In 2010, county-assignments in several German states were changed, and it became impossible to obtain the data for the old county definitions.

There are currently 402 counties (counting both Landkreise and kreisfreie Städte) in Germany (Bundesinstitut für Bau-, Stadt- und Raumforschung BBSR, 2013a). Some changes took place during the period under study. The State of Sachsen changed its county-assignment in 2008 (Sächsisches Staatsministerium für Umwelt und Landwirtschaft SMUL, 2008). As all the newer counties in Sachsen are exclusively combinations of "whole" old counties, the respective values for the new counties can be calculated by taking the (arithmetic) means or sums of the relevant variables for the old counties by weighing the influence of these old counties according to their population size. As no unemployment rates were available for 2008, the average of the unemployment rates of 2007 and 2009 of the respective new counties is taken. Sachsen-Anhalt changed its counties in 2007 (Statistisches Landesamt Sachsen-Anhalt, 2008). For neither the old, nor the new counties, is all the necessary data available for the present analysis. Thus all Sachsen-Anhalt counties are omitted from the analysis. Hannover, Aachen and Saarbrücken are left out of the analysis since they have a specific status (Regionalverband besonderer Art). The main argument for exclusion is that the various databases from which the data is collected switch between different assignments of these counties/regions. Observations for Berlin, Hamburg, and Bremen (the latter one consisting of two counties) are also dropped. These are counties and states at the same time and, thus, their legal status and administrative structure are vastly different from all other counties. Given these modifications, the analysis comprises of observations for 393 counties from 12 different states. Therefore, there is a total of 3144 observations in the balanced panel dataset used for the empirical analyses. 
Most of the economic and socio-demographic data are collected from the "Regionaldatenbank Deutschland" (2013) database. The dependent variable is the GDP per capita in a county [in Euros], as this is a general measure of the level of economic development in a county, i.e. the level of total economic output relative the size of the population. It should capture the channels (investments/income and revenue) through which the installation of wind power capacity potentially influences a county's economic development. ${ }^{7}$

The installed amount of wind capacity is one explanatory variable and the one whose coefficient is the focus of this analysis. The information on the installed wind power capacity is obtained from the Ingenieurwerkstatt Energietechnik IWET (IWET, 2013). As data exists at the postal code level, these postal codes are mapped to the German counties. ${ }^{8}$ As this data contains the pre-2008 county-borders, the values for the counties in Sachsen were updated. In the next step, the data is aggregated by year and county. As Figure 1 shows, the wind turbines are not distributed equally across the country, but are concentrated in northern Germany. In particular, the coast in the north-west has a high density of windmills. Of the 30.8 gigawatts (GW) of wind power installed at the beginning of 2013, more than half (16.9 GW) was constructed between 2002 and 2009 (IWET, 2013).

[Figure 1 "Installed onshore wind capacity in Germany" about here]

Various socio-demographic, economic (and legal) factors may play a role in determining economic development. In addition to population size in a region, the demographic composition of the population, measured by the share of the elderly, is controlled for. Moreover,

\footnotetext{
${ }^{7}$ Other measures of economic well-being, for instance wages, may be used. Wages would of course induce selection problems due to unemployment, and ignore capital income. GDP per capita, on the other hand, is a well-known and standard measure of economic development in spite of obvious shortcomings.

${ }^{8}$ See, for instance, Database-Marketing: Postleitzahlen zum Download, http://www.manfrinit.com/postleitzahlen/plz.html.
} 
the share of foreigners can have an impact (Rupasingha et al., 2002). A population's human capital also plays a role, as reflected in the share of the population with certain levels of education (Deller et al., 2001). This is captured by including three dummies based on the shares of the population with various educational attainments. ${ }^{9}$ The industry structure of the economy, as expressed by the share of the workforce working in the agricultural and in the manufacturing sector, and the respective share of males and females who are employed full time matters are also controlled for. As the counties' current job-situation may also influence regional economic growth, unemployment rates are included as control variable. Furthermore, the degree of urbanization and, thus, the composition of the economy possibly lead to different economic growth rates (Bertinelli and Black, 2004). This point is operationalized by including four county category-dummies based on the definitions reported in Figure A1 in the appendix. This figure shows the structure of the German counties in 2010 (no categorization prior to this was available). ${ }^{10}$ From the figure it is notable that the share of urban counties is higher in the Western part of Germany than in the East.

[Table 1 "Descriptive statistics" about here]

Table 1 shows the summary statistics for the variables over the 2002-2009 period. Note that the installed wind capacity is the accumulatively ${ }^{11}$ installed wind capacity, since 2002, per county. The table reveals that for both installed wind capacity and the wind potential, the standard deviation is very high compared to the respective mean values. This mirrors what is shown in Figure 1, namely that the installed wind capacity is distributed unequally across

\footnotetext{
${ }^{9}$ For about $13 \%$ of the population, no information concerning their educational attainment was available. This group is assumed to come proportionally from the three included education groups.

${ }^{10}$ The county categories are included as time-independent dummies.

${ }^{11}$ Thus, this is the sum of all installed wind power capacity since 2002 . The later-on introduced stateor county dummies may capture the pre-2002 installed wind capacity.
} 
Germany, and the same is true for the wind instrument, which is discussed in the next section. The standard deviation of the GDP per capita is about $40 \%$ of its mean value, indicating that a certain degree of equality, with some variation between the German counties, exists.

In addition the relative growth in GDP per capita from 2002 to 2009 is investigated, splitting the sample based on whether the counties (i) already had wind power instalments before 2002; (ii) counties that got wind power instalments for the first time during the sample period; and (iii) those counties that neither had any wind power instalments in the beginning of nor at the end of the sample period (the share of counties in the respective groups are; $65.4 \%$, $7.6 \%$, and $27.0 \%) .{ }^{12}$ GDP growth is largest in the first group, while the smallest growth is found in the last group. ${ }^{13}$ It is an open question, though, whether the differences are caused by wind power instalments, or whether the differences are driven by confounding factors.

\subsection{Econometric Specification}

To identify the effect of the wind power deployment on the economic development in a county the following model is estimated

$$
\ln \text { GDPcap }_{i t}=\beta_{0}+\beta_{1} \text { InstWind }_{i t}+\text { SocioEcControl }_{i t}{ }^{\prime} \eta+\text { EconUrban }_{i t}{ }^{\prime} \delta+\tau_{t}+v_{i t}
$$

where the subscripts $i$ denotes county, and $t$ denotes year. $\ln$ GDPcap is the log-transformed GDP per capita, InstWind is the installed wind capacity. The SocioEcControl is a vector containing socio-economic- and demographic variables; population size, elderly share, foreigner share, and little and some education share. ${ }^{14}$ The EconUrban is a vector with variables

\footnotetext{
${ }^{12}$ Detailed numbers for the three sub-groups of counties are available from the authors on request.

${ }^{13}$ The difference in the mean value of economic growth is statistically significant comparing the first and last groups, while the two other differences are not.

${ }^{14}$ The share of the population with a high education share serves as baseline.
} 
describing the industry structure and the labour market, as well as the urbanization; agricultural employment share, manufacturing share, unemployment rate and the share of the male (female) labour force working full time. Time dummies $\tau_{t}$ are also included to control for macro shocks' effects. The residual vit might include unobservable county specific components, such as political differences, preferences, regulations that all may vary between the counties. ${ }^{15}$

The regressor of greatest interest to this study is the InstWind. Given the functional form of the dependent variable and the InstWind variable, the coefficient in front of the latter variable, $\beta_{1}$, reflects how large the percentage change in GDP per capita is when the InstWind capacity is increased by one unit [here: gigawatt].

As a number of laws and regulations concerning wind power and environmental policies are passed at the state level in Germany, economic growth across German states may differ. Thus, to allow for potential state specific effects, 11 state dummies are included.

The model described by equation (7) is first estimated with a pooled OLS estimator. This assumes that each observation is independent from the others. Yet, wind power capacity investments may partly be motivated by regional development policies. The question of whether or not wind farms are implemented highly depends on the perception that both local authorities and the population have of the local economic impacts (Mulvaney et al., 2013; Toke, 2005). In the existing dataset, there is no consistent information available for this. ${ }^{16}$ If it does play a role, though, the pooled OLS estimates will be biased. To account for these unobserved

\footnotetext{
${ }^{15}$ Some of these components might be observable, for instance political preferences and regulations. However, for this study we do not have such information, and these effects will therefore be picked up by the county specific effects in the error term.

${ }^{16}$ In their analysis of wind farm development projects on the Shetland Islands, Allan et al. (2011) find that the ownership structures have great influences on local economic impacts. For Germany, reliable numbers about the share of wind projects where local residents are at least partial owners are highly uncertain (see for instance the discussion in Szarka and Blühdorn, 2006). Numbers limited to cooperatives show that these have only had economic significance since 2009, as less than 20 of these existed in the whole of Germany before 2009 (German Wind Energy Association, 2012). Deutsche WindGuard (2015), on the other hand, argues that local ownership played a major role already before 2009.
} 
county-specific factors and potential dependency over time for each county, the residual $v_{i t}$ is decomposed into a county-specific term, $f_{i}$, and an idiosyncratic error term, $u_{i t}$. The resulting equation is estimated with both a random effects and a fixed effects estimator. The former assumes that the explanatory variables are independent of the unobserved county specific effects. The fixed effects model also drops this assumption, but is generally less efficient than the random effects model. Hence, after running the pooled OLS, random effects and fixed effects regressions, a Hausman specification test is conducted. It validates whether the explanatory variables are indeed independent of the unobserved county specific effects. If so, the random effects models' estimates are to be preferred over the fixed effects' ones.

\section{Instrumental variable}

In case of a feedback process of the economic growth onto the installation of wind power capacity, the estimation results will be biased. This endogeneity bias can be dealt with by using an instrumental variable approach. A county's wind potential is a possible instrument for the installed wind capacity. The critical assumption for the chosen instrumental variable, potential wind capacity, is that it should only affect the indicator of economic welfare through changes in installed wind capacity, without a direct effect. It seems unlikely that the weather condition or wind should have a direct effect on the GDP per capita. ${ }^{17}$ Thus the exclusion restriction seems to be fulfilled. The discussion is supplemented with an endogeneity test; the difference of two Sargan-Hansen tests is taken, where one treats the regressor as endogenous and one treats them as exogenous. A significant difference indicates exogeneity of the instrument. The Kleibergen-Paap test, a robust variant of the Stock and Yogo (2005), is used to check the validity of the instruments (see Baum et al., 2007). This is complimented by a simple $F$-test of

\footnotetext{
${ }^{17}$ Wind conditions might have affected a country's industry composition for historical reasons; in the regressions there are controls for industry composition and urbanisation.
} 
the instruments in the first stage regression in two stage least squares (2SLS), see Staiger and Stock (1997).

The wind potential is based on a county's particular natural attributes, including its wind strength, unevenness of ground, elevation and geographic location. ${ }^{18}$ For every square kilometre, the wind generation potential over a five-year period for a specific turbine is measured (source: DWD 2013). Next, the calculated wind potentials are set in relation to the electricity a turbine would generate in "standard" conditions, as described in the German feedin tariff (German Bundestag, 2011). ${ }^{19}$ Since only areas where the wind return is above $60 \%$ of this standard value are eligible for the German feed-in tariff (and are thus interesting for investors), areas are ignored where the expected wind return is below this $60 \%$ threshold. ${ }^{20}$ Finally, the wind potential for every square kilometre spot in a county is summed up. ${ }^{21}$

[Figure 2 "Wind Energy Potential in Germany" about here]

Wind energy potential in mainland Germany is shown in Figure 2. In the black areas, the expected wind return is below the aforementioned $60 \%$-threshold. The white areas are regions where wind power deployment is more likely due to excellent wind conditions (more than $100 \%$ of the standard scenario). In line with their actually installed wind capacity, the northern German coastal areas have a high wind potential, while many parts of southern Germany fall below the $60 \%$ of the reference value. Examining Figure 1 and Figure 2 together,

\footnotetext{
${ }^{18}$ Note that it is not only the average wind speed at a location, but also the distribution of the wind speeds that matters for whether or not a location is a suitable for wind power deployment (DWD, 2013). ${ }^{19}$ The feed-in tariff provides investors with financial incentives to deploy wind power, as they are paid a certain amount of money for all electricity produced, which is dependent on wind strength. This amount depends on the suitability of the area where the wind turbines stand, operationalized through the introduction of a "standard" location, to which the actually produced amount of electricity is compared. ${ }^{20}$ In the version of the support scheme that applied in the sample period.

${ }^{21}$ In the quite frequent cases where one square kilometre spot reaches into two (or more) counties, it is assigned to the county with which it has the largest overlap.
} 
it can be seen that, as hypothesized for the construction of the instrumental variable, wind potential and actual wind capacity installations often go together. Furthermore, it is noteworthy that also areas that do not have the highest wind potential can have large amounts of installed wind capacity, e.g. in middle and eastern Germany.

One last modification is done with the potential instrument. For each year in the sample period, the annual share of the total amount of new wind installations over the whole sample period is calculated at the national level giving an annual (but cross-sectionally invariant) share variable. This share might serve as proxy for the general interest or attitude regarding green energy in Germany. This share in itself is unlikely to be correlated with the county specific annual economic development. Finally, the product of the annual installed wind capacity share and the county-specific time-invariant wind potential is taken. Thus, we end up with a timevarying county-specific instrument that is correlated with the annual county specific wind installations, but (most likely) uncorrelated with the annual county-specific GDP per capita measure.

\section{Empirical results}

The results of the pooled OLS, random effects, and fixed effects are displayed in Table $2 .{ }^{22}$

[Table 2 "Empirical results" about here]

Starting with the pooled OLS results reported in column (1), it can be seen that installed wind power capacity has a statistically significant effect with an increase of $1 \mathrm{GW}$ installed wind power resulting in an increase of $0.389 \%$ in GDP per capita.

\footnotetext{
${ }^{22}$ All the reported standard errors are clustered at the county level, making them asymptotically robust to both heteroscedasticity and serial correlation.
} 
A quick look at the control variables, focusing on the statistically significant ones, shows that the share of foreigners has a positive effect on GDP per capita. This might be as this variable is picking up the effect of bigger cities, instead of the urbanization dummies (which are statistically insignificant). Areas with higher shares of people with little or only some education tend to fare worse economically. Moreover, a higher share of females working full time has a positive impact, whereas the opposite is true for a higher male full time working share. The industry composition dummies are consistent with the prior beliefs, with somewhat lower GDP in areas with a higher share of labour force in the agriculture industry, and the opposite effects when a larger share is working in the manufacturing industry. Finally, unemployment has a negative effect on the GDP per capita.

In column (2), unobserved county specific effects are allowed for by using a random effects model. Now the effect of installed wind power production capacity has become statistically insignificant, and negative. This means that economically-attractive counties are also more likely to install wind capacity. Such factors could be unobserved factors like a county's actual quality of the infrastructure, political differences, or the efficiency and structure of its administration. Cultural differences like the inhabitants' working attitude and their general attitude toward self-employment could also be captured in these locational factors. ${ }^{23}$ Hence, the existence of such a dependence of GDP per capita on these factors renders the OLS results biased. The significant effect found in the OLS regression is due to omitted unobserved countyspecific differences. In the random effects specification, the effects of the controls are even more significant, as can be seen in column (2), relative to what is seen in column (1).

\footnotetext{
${ }^{23}$ An additional factor might be the actual ownership-structure of the German wind projects, which is unclear, as discussed in the introduction. A positive correlation between unobservable factors and wind turbine installations could explain why counties that have rather positive locational factors also install more wind power, since they simply have a better cultural, structural and financial setup. Hence, there is correlation between the unobserved factors and the installation of wind power and, consequently, the change of signs between the linear and the fixed effects estimates.
} 
However, also the random effects results are only unbiased under the assumption that the explanatory variables and the unobserved county specific effects are independent. If this is not the case, a remedy is the fixed effects model, which allows for such dependencies. When testing whether the coefficient vectors of the random effect model and the fixed effect model are the same, using the Hausman test, the null hypothesis of no difference is strongly rejected $\left(\chi_{d f=11}^{2}=228.04\right)$. Thus, there are dependencies between the explanatory variables and the unobserved county specific effects. Therefore, the fixed effects estimates are preferred over the random effects estimates and the pooled OLS.

The results of the fixed effects model are reported in column (3). Again there is the negative, but statistically insignificant, effect of additional units of installed wind power capacity. The difference to the significant and positive OLS estimate might be due to a correlation between the mentioned unobserved factors $f_{i}$ and the installation of wind power, as described in the above paragraphs. Turning to the other control variables, the elderly share and agricultural employment share have lost significance/dropped strongly. This is possibly the case because these variables do not vary much over time and thus are picked up by the fixed countyspecific effect $f_{\text {i. }}$

\section{Robustness checks}

When using the fixed effects model (as well as the pooled OLS and the random effect model), it is implicitly assumed that the cross-sectional units, the counties, are independent and that there is no cross-sectional dependency in the error term. Thus, one implicitly says for instance that there are no neighbourhood effects or common preferences across counties. Otherwise, the existence of such cross-sectional dependencies would render the FE and RE estimates biased and inconsistent. Given that the units in this analysis are counties, with an average population of 187,000 , it seems reasonable to believe that, for instance, GDP per capita, both level and 
growth, depends on financial and political integration between the counties, as well as characteristics and the performance of neighbouring counties. Such factors create strong interdependencies between the counties. ${ }^{24}$ Two statistical procedures designed to test for crosssectional dependence in the error term in panels are utilized (Pesaran, 2004 and Friedman, 1937); both implemented in STATA (see De Hoyos and Sarafidis, 2006). The basic idea behind these tests is to calculate an overall correlation coefficient based on all the potential parings of the residuals of the various cross-sectional units (here, counties). The null hypotheses are that there is no cross-sectional dependency. Pesaran's $(p$-value $=0.53)$ and Friedman's $(p$-value $=1.00)$ tests fail to reject the null-hypothesis of no cross-sectional dependence. Stated differently, cross-sectional dependency does not invalidate the estimated results.

The fixed effect specification can be seen as a way to control for unobserved selection effects, if the selection effect is constant over time and is correlated with the unobserved characteristics of the analysed counties. In addition, this analysis addresses the potential feedback process from the economic development onto the installation of wind power capacity by using a fixed effects instrumental variable method. A county's wind potential is used as a possible instrument for the installed wind capacity. The results of this IV estimation are reported in Table 2, column (4). The estimates from the fixed effect IV approach do not lead to a change in the estimated effect of installed wind capacity; the estimate is nearly identical to that of the standard FE-model. Focusing on the relevant IV test statistics, the Kleibergen-Paap test indicates that the instrument is highly relevant (i.e., no weak instrument problem). In addition, the $F$-test $(=10.90)$ used to test the relevance of the instrument in the first stage of the 2SLS reaches their "rule of thumb" value of 10 . What is more is that the endogeneity test, $p$-value equal to 0.17 , yields that endogeneity is not a problem in this case. This is probably because the

\footnotetext{
${ }^{24}$ Differences between the states, for instance regional/state specific policies, are controlled for by the state dummies, which in the county fixed effect model are picked up by the county fixed effects.
} 
normal fixed effects estimator already allows for unobserved locational factors that influence both economic growth and the installation of wind capacity. Hence, endogeneity of the installed wind capacity is not an issue. ${ }^{25}$ But most importantly, just like the regular FE model, the FE-IV results show statistically insignificant effects of the installed wind capacity on the economic development of German counties.

Even though all the reported standard errors are clustered at county level and therefore robust to potential heteroscedasticity and serial correlation, testing of the heretofore preferred FE model reveals the presence of positive autocorrelation. ${ }^{26}$ A probable explanation for this autocorrelation is mis-specified dynamics - in particular, the reliance so far on a completely static model specification. It is definitely true that wind power installations are long-term projects such that each year's optimization problem is unlikely to be uncorrelated with the ones in previous years. This is implemented in a very simple and ad hoc way of dealing with dynamics by including a lagged dependent variable. This model can be expressed as

$$
\ln \text { GDPcap }_{i t}=\beta_{0}+\gamma \ln \text { SDPcap }_{i t-1}+\beta_{1} \ln \text { InstWindC }_{i t}+\text { SocioEcControl }_{i t}{ }^{\prime} \boldsymbol{\eta}+\text { EconUrban }_{i t}{ }^{\prime} \boldsymbol{\delta}+\tau_{t}+v_{i t}
$$

It is well known that such a dynamic model has to be estimated using an instrumental variable technique, so the Arellano-Bond (1991) GMM approach is used. The full set of results and details about instruments used of this additional model are reported in the appendix. ${ }^{27}$ The

\footnotetext{
${ }^{25}$ The view that endogeneity is not an issue is supported when looking at the results from a specification where one only utilizes the differences between the counties, and not within each group - then exogeneity of the installed wind capacity cannot be rejected.

${ }^{26} \mathrm{~A}$ panel data estimator which allows for first-order auto-correlation in the error term, see Baltagi and $\mathrm{Wu}$ (1999), is also used. These results show indeed that the autoregressive coefficient in the error term is positive $(=0.601)$. Most importantly, the coefficients of the installed wind power and the other control variables are very similar to the fixed effects results already reported in Table 2, column (iii). (These results are not reported, but available from the authors on request).

${ }^{27}$ This latter form, eq. (8), may be written as
} 
most important aspect, when looking at the dynamic model results, is that the coefficient, $\beta_{1}$, for the wind power instalment is still statistically insignificant. Thus, dynamic mis-specification is unlikely to be the explanation for the findings that installation of wind power capacity does not have a significant impact on GDP per capita. ${ }^{28}$

An interesting question when one analyses the effect of wind power instalments in a county is whether the effects are due to the profitability on intensive margin (the effect of an additional unit in areas with already existing installations) or to the extensive margin (going from zero to something). For this study, 257 out of the 393 counties had some wind power installed before sample period. Only 30 counties that did not have wind power before the sample period installed wind power during the sample period ( $7.6 \%$ of all counties). Therefore, a major portion of new installations were made in counties where previous installations existed, such that the results are driven by contributions on the intensive margin. One might think that using wind power as an instrument for regional development might be relevant in rural areas with no wind power installations. Such zero to something installations may also lead to positive externalities, for instance a positive business climate and atmosphere among firms and consumers, externalities that might affect the productivity and income in a county. With preexisting wind power installations one could think that such externalities are marginal, as this analysis finds.

This section is concluded with a brief comparison to previous findings. The overall result in this study is that installed wind power does not affect economic development in

$$
\begin{aligned}
\Delta \ln \text { GDPcap }_{i t} & =\ln \text { GDPcap }_{i t}-\ln \text { GDPcap }_{i t-1} \\
& =\beta_{0}+\theta \ln \text { GDPcap }_{i t-1}+\beta_{1} \ln \text { InstWindC }_{i t}+\text { SocioEcControl }_{i t}{ }^{\prime} \boldsymbol{\eta}+\text { EconUrban }_{i t}{ }^{\prime} \boldsymbol{\delta}+\tau_{t}+v_{i t}
\end{aligned}
$$

where $\theta=(\gamma-1)$. This formulation is consistent with the growth model by Barro (1991). The estimated $\theta=\gamma-1=0.719-1=-0.281$ states that as GDP per capita increases, growth slows down.

${ }^{28}$ Interestingly, the coefficient of the lagged dependent variable $\gamma$ and the auto-regressive coefficient in the error term when applying the Baltagi-Wu estimator (see footnote 26) appear to be quite close. This might indicate that the dynamic specification could be driven by persistency in the error terms of the static model described by equation (7). 
German counties. In the US, counties where wind power is installed, e.g. the Great Plains and Texas, are typically extremely rural. ${ }^{29}$ When investments in these areas are made, this potentially yields much higher side-effects, like investments in local infrastructure or a shift away from agriculture. In Germany, the counties are rather industrialized even without wind power investments. Therefore, such investments do not bring any particularly strong sideeffects with them. Furthermore, almost all counties that installed wind power in the sample period had already installed capacity beforehand. Moreover, local in-county entrepreneurs in Germany might only to a small degree be able to participate in the implementation of the projects due to the generally shorter distances between counties. Thus, wind park investors are more likely to use out-of-county contractors. Another potential explanation is the ownership structure, as a higher share of locally-owned projects might lead to greater local economic impacts of these projects. The actual prevalence of local ownership structures is unclear and, consequently, its economic implications. Moreover, the results are in line with previous findings for the effects of a particular wind power project around the German city of Hannover as found by Schröder (2010), and with the findings for Wales by Munday et al. (2011) and Bristow et al. (2012), who all find no or only marginal effects.

\section{Concluding remarks}

Wind power deployment in many countries depends on the decisions of local planning authorities. These decisions, along with public opinion about wind farms, are shaped by the perception of the local economic impacts of such projects. Often it is argued that such wind power deployment will be economically beneficial for the area and, among other things, that

\footnotetext{
${ }^{29}$ The difference in results compared to Brown et al. (2012) does not stem from the different methodological approach. It remains also when applying an estimator similar to their quasi-crosssectional one.
} 
such wind power deployment will positively affect regional GDP per capita. Germany is not an exception to this conjecture.

In this study we estimate the local economic impacts of wind power deployment in Germany. Importantly, we look at the very county only where the turbines are located. Countrywide effects of wind power deployment have up to now received considerably more attention in the literature. Furthermore, this study addresses the potential endogeneity of wind power installations through a panel data setup. Such endogeneity could arise if the decision to install wind turbines in a county depends on that county's economic performance. Through the use of panel data for Germany for the period between 2002 and 2009, such effects are controlled for.

The pooled OLS yields that a (very large) $1 \mathrm{GW}$ wind power project increases a county's GDP per capita by $0.389 \%$. Yet, as this estimate is biased due to omitted county specific effects, it is argued that the fixed effects estimate is superior. This estimate, on the other hand, signals that the estimates give insignificance-results for the installed wind capacity. Taking into account that the installed wind capacity over this period could be endogenous, an instrument is created based on the counties' wind potential. The estimation results affirm the insignificance of the installation of wind farms for local economies.

These findings are interesting in light of a number of studies for American counties where wind power deployment is found to have an economically significant impact. Yet, the few existing European studies, focused on Wales and the Shetland Islands in the UK as well as Hannover in Germany also indicate that there are only limited, if any, local economic impacts in these areas. The conceptual framework shows that besides pure local economic incentives for counties to install wind power, such installations can also be pushed forward due to other aspects of wind power.

Our findings, both in the theoretical framework and the empirical analysis, along with existing European results, indicate that the importance of wind power for local economic 
development is marginal. These findings lend support to the notion that wind farm consents is more complex than mere local economic reasons. National/international bodies decide on renewable energy growth targets. Thus, the local economic effect will be hard to observe and might not be the only driving force green policies in general, and wind power installations more specifically. Whether this conclusion is robust to other regions and other countries remains to be seen (and is beyond the scope of this paper). Thus, the growth of wind power deployment is, seen from a local perspective, likely to be driven by considerations like the associated reductions in greenhouse gas emissions, country-wide economic impacts and active industry policy, rather than by pure local economic considerations. However, German local governmental policy-makers, in line with local decision-makers in most other countries, decide on whether and where projectors can erect wind turbines, so that their local decision about expected outcomes is crucial for wind power projects. A limitation of this study is that local decision-makers might very well have expectations that wind projects will increase economic welfare in their county, even though these expectations - on average - appear not to hold. As we do not have empirical information on counties' and projects' decision-making processes, further research into these expectations of involved policy-makers would add value to this debate. 


\section{References}

Allan, G., McGregor, P. and Swales, K. (2011), "The Importance of Revenue Sharing for the Local Economic Impacts of a Renewable Energy Project: A Social Accounting Matrix Approach", Regional Studies, Vol. 45 No. 9, pp. 1171-1186. doi: 10.1080/00343404.2010.497132.

Arellano, M. and Bond, S. (1991), "Some Tests of Specification for Panel Data: Monte Carlo Evidence and an Application to Employment Equations", The Review of Economic Studies, Vol. 58 No. 2, pp. 277-297. doi: 10.2307/2297968

Barro, R.J. (1991), "Economic Growth in a Cross Section of Countries", The Quarterly Journal of Economics, Vol. 106 No. 2, pp. 407-443. doi: 10.2307/2937943.

Baum, C. F., Schaffer, M. E., and Stillman, S. (2007), "Enhanced routines for instrumental variables/GMM estimation and testing", Stata Journal, 7(4), 465-506.

Baltagi, B. H. and Wu, P. X. (1999). "Unequally spaced panel data regressions with AR(1) disturbances" Econometric Theory, pp. 814-823. doi: 10.1017/S0266466699156020.

BBSR (2011), "Raumgliederung auf Kreisbasis. Siedlungsstrukturelle Kreistypen“, Das Bundesinstitut für Bau-, Stadt- und Raumforschung, Bonn, available at: http://www.bbsr.bund.de/cln_032/nn_1086478/BBSR/DE/Raumbeobachtung/Raumabgren zungen/Kreistypen4/Download_Karte2011__ PDF,templateId=raw,property=publication File.pdf/Download_Karte2011_pdf.pdf, used with permission from the authors.

BBSR (2013a), "Laufende Raumbeobachtung - Raumabgrenzungen. Kreise und Kreisregionen“, Das Bundesinstitut für Bau-, Stadt- und Raumforschung, Bonn, available at:

http://www.bbsr.bund.de/nn_1067638/BBSR/DE/Raumbeobachtung/Raumabgrenzungen/ Kreise Kreisregionen/kreise node.html? nnn=true.

Bertinelli, L. and Black, D. (2004), "Urbanization and growth", Journal of Urban Economics, Vol. 56 No. 1, pp. 80-96. doi: 10.1016/j.jue.2004.03.003.

BMU (2011), “ Das Energiekonzept der Bundesregierung 2010 und die Energiewende 2011“, Bundesministerium für Umwelt, Naturschutz, Bau und Reaktorsicherheit, Berlin, October 2011, available at: http://www.bmub.bund.de/fileadmin/bmu-import/files/pdfs/allgemein /application/pdf/ energiekonzept_bundesregierung.pdf

Bristow, G., Cowell, R. and Munday, M. (2012), "Windfalls for whom? The evolving notion of 'community' in community benefit provisions from wind farms", Geoforum, Vol. 43 No. 6, pp. 1108-1120. doi: 10.1016/j.geoforum.2012.06.015.

Brown, J.P., Pender, J., Wiser, R., Lantz, E. and Hoen, B. (2012), "Ex post analysis of economic impacts from wind power development in U.S. counties", Energy Economics, Vol. 34 No. 6, pp. 1743-1754. doi: 10.1016/j.eneco.2012.07.010.

Butler, L. and Neuhoff, K. (2008), "Comparison of feed-in tariff, quota and auction mechanisms to support wind power development", Renewable Energy, Vol. 33 No. 8, pp. 1854-1867. doi: 10.1016/j.renene.2007.10.008.

De Hoyos, R. E., and Sarafidis, V. (2006), "Testing for cross-sectional dependence in paneldata models", Stata Journal, 6(4), pp. 482-496.

Deller, S.C., Tsai, T.-H., Marcouiller, D.W. and English, D.B. (2001), "The Role of Amenities and Quality of Life in Rural Economic Growth", American Journal of Agricultural Economics, Vol. 83 No. 2, pp. 352-365. doi: 10.1111/0002-9092.00161.

DWD (2013), “ Karten und Daten zur Windkraftnutzungseignung Referenzertragskriterium nach EEG“, Bezugszeitraum 1980-2000, Deutscher Wetterdienst, Offenbach.

Deutsche WindGuard (2015), "Akteursstrukturen von Windenergieprojekten in Deutschland“, Varel. 
Friedman, M. (1937), "The use of ranks to avoid the assumption of normality implicit in the analysis of variance", Journal of the American Statistical Association, 32(200), 675-701.

Geodatenzentrum (2009), "Verwaltungsgebiete 1:250.000“, Leipzig, available at: http://www.geodatenzentrum.de/auftrag1/archiv/vektor/vg2500/de1109/vg2500_geo84.zip.

German Bundestag (2011), "Gesetz zur Neuregelung des Rechtsrahmens für die Förderung der Stromerzeugung aus erneuerbaren Energien", Berlin, July 28, 2011.

German Wind Energy Association (2012), "Community Wind Power. Local energy for local people", German Wind Energy Association (BWE), Berlin, available at: http://www.windenergie.de/sites/default/files/download/publication/community-windpower/ bwe_broschuere_buergerwindparks_engl_10-2012.pdf.

Global Wind Energy Council (2015), "Global Wind Statistics 2014”, available at: http://www.gwec.net/wpcontent/uploads/2015/02/GWEC_GlobalWindStats2014_FINAL_10.2.2015.pdf.

Greene, J. and Geisken, M. (2013), "Socioeconomic impacts of wind farm development: a case study of Weatherford, Oklahoma", Energy, Sustainability and Society, Vol. 3 No. 1, pp. 19. doi: 10.1186/2192-0567-3-2.

Hitaj, C. (2013), "Wind power development in the United States", Journal of Environmental Economics and Management, Vol. 65 No. 3, pp. 394-410. doi: 10.1016/j.jeem.2012.10.003.

International Energy Agency (2012), "World Energy Outlook 2012 Factsheet. How will global energy markets evolve to 2035?", Paris, available at: http://www.worldenergyoutlook.org/media/weowebsite/2012/factsheets.pdf

IWES (2012), "Wind Report Deutschland 2011", Fraunhofer IWES, Kassel/Bremerhaven, available at http://windmonitor.iwes.fraunhofer.de/bilder/upload/Windreport 2011_de.pdf, used with permission from the authors.

IWET (2013), „Übersicht Windenergieanlagen Deutschland “, Ingenieurwerkstatt Energietechnik, Hamburg.

Mulvaney, K.K., Woodson, P. and Prokopy, L.S. (2013), "A tale of three counties: Understanding wind development in the rural Midwestern United States", Energy Policy, Vol. 56, pp. 322-330. doi: 10.1016/j.enpol.2012.12.064.

Munday, M., Bristow, G. and Cowell, R. (2011), "Wind farms in rural areas: How far do community benefits from wind farms represent a local economic development opportunity?", Journal of Rural Studies, Vol. 27 No. 1, pp. 1-12. doi: 10.1016/j.jrurstud.2010.08.003.

Pesaran, M. H (2004), “General Diagnostic Tests for Cross Section Dependence in Panels”, IZA Discussion Paper No. 1240.

Regionaldatenbank Deutschland (2013), “County data”, Statistische Ämter des Bundes und der Länder, Düsseldorf.

Ren21 (2014), „Renewables 2014 - Global Status Report, Ren21, Paris, France, available at http://www.ren21.net/Portals/0/documents/Resources/GSR/2014/GSR2014_full\%20report low\%20res.pdf.

Rey, S. J. (2000), "Integrated regional econometric+input-output modeling: Issues and opportunities", Papers in Regional Science, Vol. 79, No. 3, pp. 271-292, doi: 10.1111/j.1435-5597.2000.tb00772.x.

Roodman, D. 2009, "How to do xtabond2: An introduction to difference and system GMM in Stata”, Stata Journal 9(1), pp. 86-136.

Rupasingha, A., Goetz, S.J. and Freshwater, D. (2002), "Social and institutional factors as determinants of economic growth: Evidence from the United States counties", Papers in Regional Science, Vol. 81 No. 2, pp. 139-155. doi: 10.1007/s101100100091.

Schröder, A. (2010), "Regionalökonomische Effekte aus der Nutzung von Windenergie in der Region Hannover", Working materials 100EE nr. 3, deENet, Kassel. 
Slattery, M. C., Lantz, E. and Johnson, B. L., "State and local economic impacts from wind energy projects: Texas case study”, Energy Policy, Vol. 39, Issue 12, December 2011, pp. 7930-7940, doi:10.1016/j.enpol.2011.09.047.

SMUL (2008), "Hintergrundinformationen zur Kreisgebiets- und Verwaltungsreform. Neue Landkreisstruktur - zuständige Landratsämter“, Sächsisches Staatsministerium für Umwelt und Landwirtschaft, Dresden, available at: http://www.smul.sachsen.de/smul/7291.htm

Staiger, D. and Stock, J. H. (1997), "Instrumental variables regression with weak instruments" Econometrica 65(3), pp. 557-86. doi: 10.3386/t0151.

Statista (2014), "Anteil erneuerbarer Energieträger an der Bruttostromerzeugung in Deutschland im Jahr 2013“, Statista GmbH, Hamburg.

Statistisches Landesamt Sachsen-Anhalt (2008), "Kreisgebietsreform am 1. Juli 2007", Kamenz, available at: http://www.stala.sachsen-anhalt.de/gk/and/gk.aktuell. kreisgrenzen_2007.html.

Stock, J. H. and Yogo, M. (2005), "Testing for Weak Instruments in Linear IV Regression. Identification and Inference for Econometric Models", Essays in Honor of Thomas Rothenberg, pp. 80-108.

Szarka, J. and Blühdorn, I. (2006), "Wind Power in Britain and Germany: Explaining contrasting development paths", Anglo-German Foundation for the Study of Industrial Society, November 2006. doi: 10.1016/j.enpol.2005.05.011.

Toke, D. (2005), "Explaining wind power planning outcomes", Energy Policy, Vol. 33 No. 12, pp. 1527-1539. doi: 10.1016/j.enpol.2004.01.009.

Turner, K. Munday, M., McGregor, Peter and Swales, Kim (2012), "How responsible is a region for its carbon emissions? An empirical general equilibrium analysis", Ecological Economics, Vol 76, April 2012, pp. 70-78, doi: 10.1111/j.1435-5957.2011.00365.x.

Yue, C.-D., Liu, C.-M. and Liou, E.M. (2001), "A transition toward a sustainable energy future: feasibility assessment and development strategies of wind power in Taiwan", Energy Policy, Vol. 29 No. 12, pp. 951-963. doi: 10.1016/S0301-4215(01)00025-8. 


\section{Appendix: About the dynamic model estimation}

The lagged dependent variable in the panel data model induces endogeneity issues, and the procedure suggested by Arellano-Bond (1991), implemented in STATA (xtabond2, see Roodman, 2009), is implemented. That means, first the county specific terms are removed by estimating the model in first differences, and the first-difference of the lagged dependent variable - the GDP per capita - is instrumented by GDP per capita in levels, lagged $t-2$ to $t-4$ in a GMM setup. The number of lags is restricted so that the Hansen test statistic is unlikelier to get biased due to instrument-proliferation. The results of the Arellano-Bond procedure are shown in Table A1.

[Table A1 about here]

The test statistics justify the dynamic specification: As expected, there is no second order auto-correlation in differences, so the dynamic specification is trust-worthy and no further lagged dependent variables need to be included. The Hansen test, unbiased in case of heteroscedasticity and auto-correlation, states that all instruments are indeed exogenous on a 5\% significance level.

The coefficient of the lagged dependent variable, 0.719 , is statistically significant. Most importantly, the coefficient of the installed wind capacity is statistically insignificant also in this specification. 
Table 1: Descriptive statistics of the variables for the period 2002-2009

\begin{tabular}{|c|c|c|c|}
\hline Variable & Mean & Std. dev. & Add. description \\
\hline GDP per capita* & 26511.95 & 10450.78 & \\
\hline Installed wind capacity** & 22503.580 & 51065.230 & cumulative amount in MW \\
\hline Wind potential (instrument) ${ }^{* * *}$ & 1102937 & 1493907 & \\
\hline Population* & 18.690 & 14.344 & in 100,000 \\
\hline Elderly share* & 0.196 & 0.023 & $<=65$ years \\
\hline Foreigner share* & 0.073 & 0.045 & \\
\hline Little education share* & 0.184 & 0.047 & no job qualification \\
\hline Some education share* & 0.720 & 0.066 & some job qualification \\
\hline Higher education share* & 0.096 & 0.044 & higher univ. degree \\
\hline Agricultural empl. share* & 0.032 & 0.024 & \\
\hline Manuf. empl. share* & 0.220 & 0.086 & \\
\hline Male FTEs share* & 0.955 & 0.019 & $\%$ of men work. full-time \\
\hline Female FTEs share* & 0.673 & 0.045 & $\%$ of women work. f.-time \\
\hline Unemployment rate* & 0.104 & 0.050 & \\
\hline Urban area $* * * *$ & 0.158 & 0.365 & \\
\hline Mostly urban area ${ }^{* * * *}$ & 0.344 & 0.475 & \\
\hline Mostly rural area**** & 0.249 & 0.433 & \\
\hline Rural area**** & 0.249 & 0.433 & \\
\hline \multicolumn{4}{|l|}{ Data sources: } \\
\hline \multicolumn{4}{|c|}{ * Regionaldatenbank Deutschland (2013) } \\
\hline \multicolumn{4}{|c|}{ ** IWET (2013) } \\
\hline \multicolumn{4}{|c|}{ *** Own calculations based on DWD (2013) } \\
\hline$* * * * \operatorname{BBSR}(2011)$ & & & \\
\hline
\end{tabular}




$\begin{array}{cccc}\text { Pooled } & \text { Random } & \text { Fixed } & \text { Fixed } \\ \text { OLS } & \text { Effects } & \text { Effects } & \text { Effects IV }\end{array}$

Dep. var.: ln of GDP/Cap. in $€$

\begin{tabular}{|c|c|c|c|c|}
\hline COEFFICIENTS & & & & \\
\hline Installed wind capacity & $0.389^{*}$ & -0.063 & -0.042 & -0.095 \\
\hline & $(0.154)$ & $(0.095)$ & $(0.096)$ & $(0.103)$ \\
\hline Population & 0.000 & -0.002 & $-0.017^{* * *}$ & $-0.017^{* * *}$ \\
\hline & $(0.001)$ & $(0.001)$ & $(0.005)$ & $(0.005)$ \\
\hline Elderly share & 0.992 & $0.921^{* *}$ & 0.363 & 0.424 \\
\hline & $(0.603)$ & $(0.322)$ & $(0.385)$ & $(0.433)$ \\
\hline Foreigner share & $1.072^{*}$ & $2.631^{* * *}$ & $1.548^{*}$ & $1.609^{*}$ \\
\hline & $(0.479)$ & $(0.421)$ & $(0.605)$ & $(0.628)$ \\
\hline Little education share & 0.244 & -0.362 & -0.090 & -0.118 \\
\hline & $(0.542)$ & $(0.320)$ & $(0.388)$ & $(0.392)$ \\
\hline Some education share & $-1.183^{* *}$ & -0.276 & 0.039 & 0.021 \\
\hline & $(0.395)$ & $(0.285)$ & $(0.346)$ & $(0.346)$ \\
\hline Agricultural empl. share & $-4.622^{* * *}$ & $-2.411^{* * *}$ & -0.559 & -0.574 \\
\hline & $(0.656)$ & $(0.625)$ & $(0.697)$ & $(0.702)$ \\
\hline Manuf. empl. share & $1.007^{* * *}$ & $0.415^{* *}$ & $0.457^{*}$ & $0.476^{*}$ \\
\hline & $(0.199)$ & $(0.161)$ & $(0.212)$ & $(0.208)$ \\
\hline Male FTEs share & $-4.675^{* * *}$ & 0.015 & 0.307 & 0.296 \\
\hline & $(0.959)$ & $(0.336)$ & $(0.326)$ & $(0.331)$ \\
\hline Female FTEs share & $1.527^{* * *}$ & $0.435^{*}$ & 0.332 & 0.331 \\
\hline & $(0.428)$ & $(0.203)$ & $(0.216)$ & $(0.214)$ \\
\hline Unemployment share & -0.433 & $-0.598^{* * *}$ & $-0.685^{* * *}$ & $-0.687^{* * *}$ \\
\hline & $(0.346)$ & $(0.134)$ & $(0.134)$ & $(0.135)$ \\
\hline Mostly urban area & $-0.092^{*}$ & $-0.244^{* * *}$ & . & \\
\hline & $(0.042)$ & $(0.047)$ & . & \\
\hline Mostly rural area & -0.025 & $-0.228^{* * *}$ & . & \\
\hline & $(0.046)$ & $(0.054)$ & . & \\
\hline Rural area & 0.028 & $-0.212^{* * *}$ & . & \\
\hline & $(0.050)$ & $(0.057)$ & . & \\
\hline TESTS & & & & \\
\hline Joint significance tests ${ }^{a}$ & & & & \\
\hline State dummies & $5.03 * * *$ & 62.17 & & \\
\hline Year dummies & $55.53 * * *$ & $621.84 * * *$ & $91.15 * * *$ & $572.35 * * *$ \\
\hline Endogeneity test ${ }^{b}$ & & & & $0.17 * * *$ \\
\hline 1SLS Joint Sign.F test & & & & $10.90 * * *$ \\
\hline Instrument relevance test ${ }^{c}$ & & & & $40.06 * * *$ \\
\hline $\mathrm{N}$ & 3144 & 3144 & 3144 & 3144 \\
\hline
\end{tabular}


Standard errors in parentheses

${ }^{*} p<0.05,{ }^{* *} p<0.01,{ }^{* * *} p<0.001$

Note: Explanatory variables measured in every year between 2002 and 2009, except for the county type variables that are measured in 2010. Year and state dummies and a constant term are also included, but are not reported individually here. Schleswig-Holstein, the year 2002, urban areas and the share of the population with a high education served as baseline scenario.

${ }^{a}$ The significance tests are a $\chi^{2}$-test for the random effects model and F-tests for the others.

${ }^{b}$ The difference of two Sargan-Hansen tests is taken. A significant difference indicates exogeneity of the instrument.

${ }^{c}$ Kleibergen-Paap Wald rk F statistic: H0: System is underidentified as the instruments are only weakly correlated with the instrumented variable. 


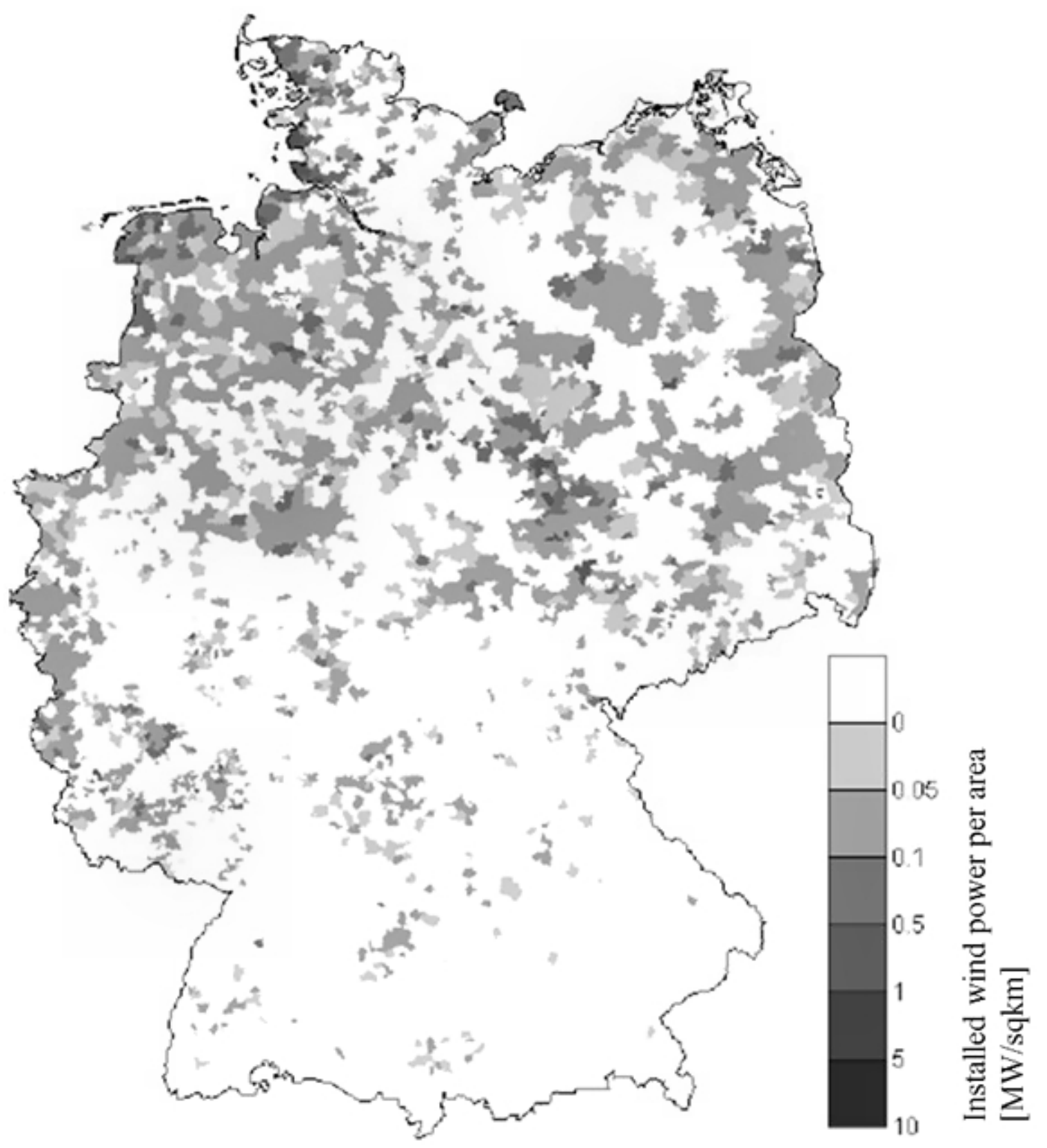

Source: Based on Fraunhofer Windenergie \& Energiesystemtechnik (IWES), 2012, based on data from Ingenieurwerkstatt Energietechnik (IWET) 


\section{Figure 2: Wind Energy Potential in Germany}

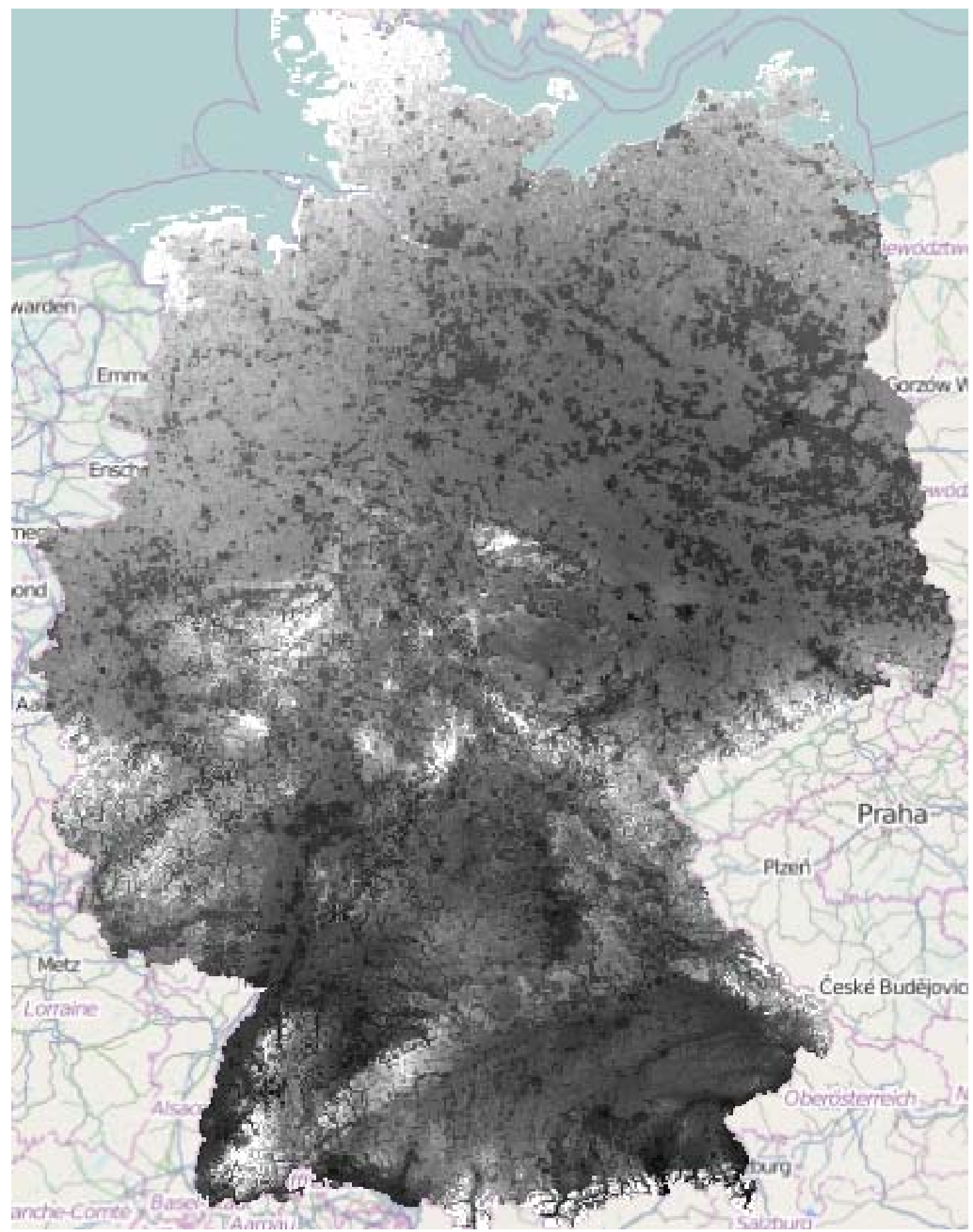

German wind energy potential $80 \mathrm{~m}$ above ground; Black: wind return $<60 \%$ of reference value; Grey: between $60 \%$ and 100\%; White: $>100 \%$. Source: Deutscher Wetterdienst (DWD) (2013) and Geodatenzentrum (2009) 
Table A1: Dynamic model estimation results

Dep. var.: In of GDP/Cap. In $€$

\begin{tabular}{|c|c|}
\hline COEFFICIENTS & \\
\hline \multirow{2}{*}{ ln of GDP/Cap lagged } & $0.719^{* *}$ \\
\hline & $(0.241)$ \\
\hline \multirow[t]{2}{*}{ Installed wind capacity } & 0.089 \\
\hline & $(0.081)$ \\
\hline \multirow[t]{2}{*}{ Population } & -0.005 \\
\hline & $(0.004)$ \\
\hline \multirow[t]{2}{*}{ Elderly share } & 0.086 \\
\hline & $(0.287)$ \\
\hline \multirow[t]{2}{*}{ Foreigner share } & 1.073 \\
\hline & $(0.587)$ \\
\hline \multirow[t]{2}{*}{ Little education share } & 0.223 \\
\hline & $(0.374)$ \\
\hline \multirow[t]{2}{*}{ Some education share } & 0.287 \\
\hline & $(0.284)$ \\
\hline \multirow[t]{2}{*}{ Agricultural empl. share } & -0.312 \\
\hline & $(0.670)$ \\
\hline \multirow[t]{2}{*}{ Manuf. empl. share } & 0.113 \\
\hline & $(0.164)$ \\
\hline \multirow[t]{2}{*}{ Male FTEs share } & -0.405 \\
\hline & $(0.274)$ \\
\hline \multirow[t]{2}{*}{ Female FTEs share } & 0.261 \\
\hline & $(0.196)$ \\
\hline \multirow[t]{2}{*}{ Unemployment share } & $-0.437^{* *}$ \\
\hline & $(0.135)$ \\
\hline \multicolumn{2}{|l|}{ TESTS } \\
\hline $\mathrm{m}^{a}$ & 0.000 \\
\hline $\mathrm{m} 2^{a}$ & 0.387 \\
\hline Hansen test of overidentification $b$ & 39.53 \\
\hline Number of instruments & 32 \\
\hline $\mathrm{N}$ & 2358 \\
\hline
\end{tabular}

Standard errors in parentheses

${ }^{*} p<0.05,{ }^{* *} p<0.01,{ }^{* * *} p<0.001$

Note: GMM results are one-step estimates with heteroskedasticity-robust standard errors and test statistics.

${ }^{a}$ A test of first-order and second-order serial correlation in first differences; asymptotically $\mathrm{N}(0,1)$.

${ }^{b}$ The minimized value of the two-step GMM criterion function, robust to heteroskedasticity and autocorrelation 


\section{Figure A1: Degree of urbanization in Germany}

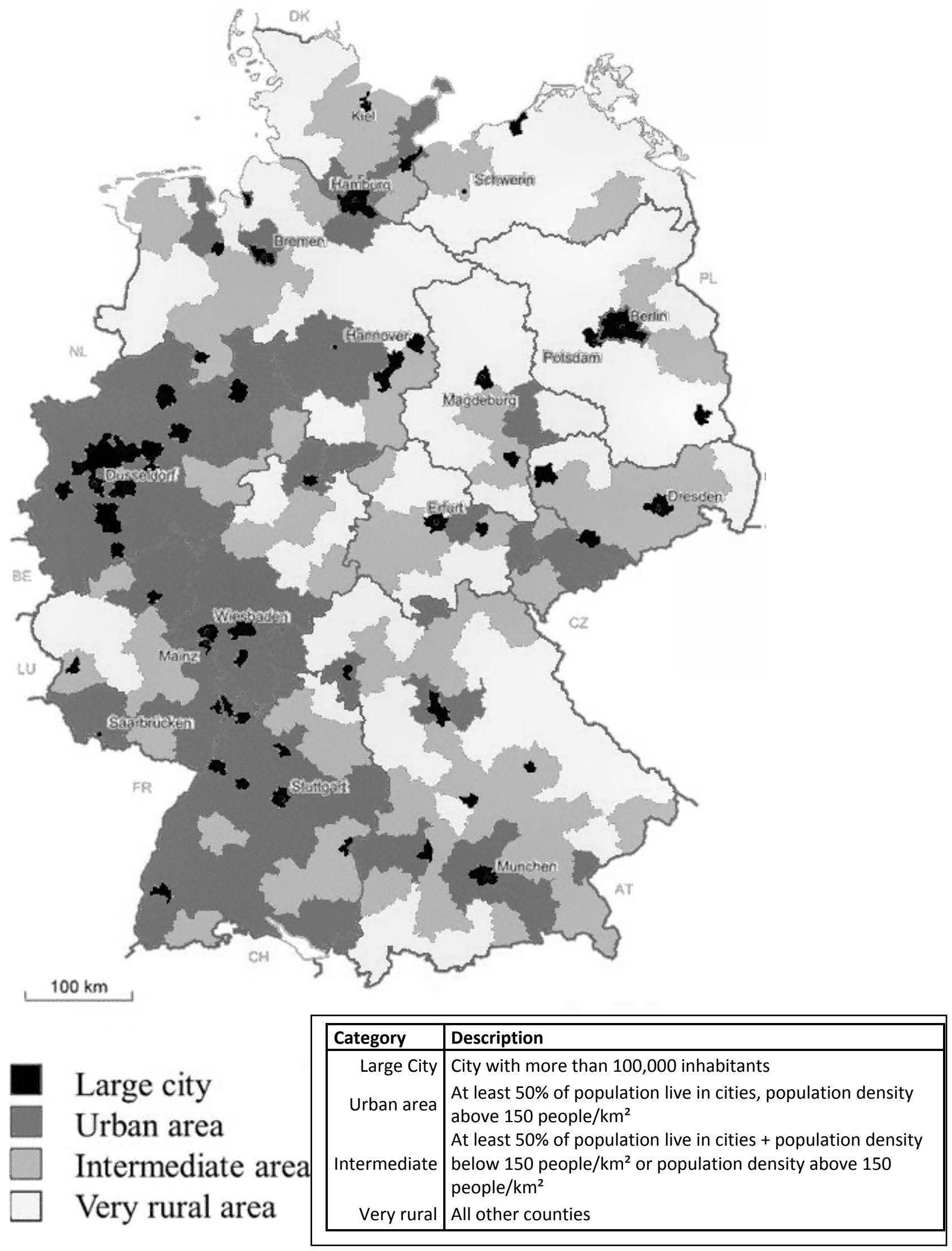

Source: Based on Bundesinstitut für Bau-, Stadt- und Raumforschung (BBSR), 2011 